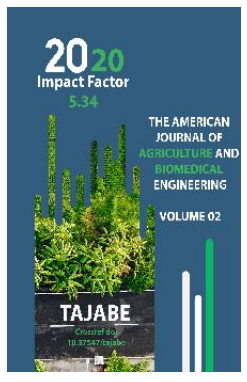

Journal Website: http://usajournalshub.c om/index,php/tajabe

Copyright: Original content from this work may be used under the terms of the creative commons attributes 4.0 licence.

\section{The Necessity Of Introducing Innovations In The Agricultural Sector Of The Republic Of Uzbekistan}

Ilimdorjon Jakhongirov

PhD, Chief Specialist of the Department of Compulsory Health Insurance of the Ministry of Health of the Republic of Uzbekistan

\title{
ABSTRACT
}

Agriculture is one of the first and most significant sectors in Uzbekistan, contributing to the national economy. Its diverse topography reveals the most favorable regions for growing various agricultural as well as industrial crops. The paper considers the features of innovation processes in agriculture, as well as the role of innovation processes in the development of agriculture in Uzbekistan. The author examines the innovative development of agriculture and highlights the main features of innovation processes; he identifies the types of innovations in the agricultural sector.

\section{KEYWORDS}

Innovations, innovation process, agriculture, innovation policy, innovation activity.

\section{INTRODUCTION}

In implementing agrarian policy, great attention should be paid to the achievement of higher final results of production activities, both in agriculture and in the entire agribusiness, ensuring stable growth rates of production, increasing its efficiency and social development of the population, protecting the economic interests of the agricultural sector.
Essential conditions for the development of innovation activity are the integration of science and production, state partnership, and support for international contacts of innovative business.

The innovation process means the innovative activity of an enterprise. It aims to develop and implement the results of scientific and technological research in the form of a new 
product or new technological process. It can be said that an innovation process is a chain of events in which an innovation "matures" from an idea to a specific product, technology, or service and then spreads in business practice.

Agricultural research has often been confused with innovation. However, there are essential differences between them. Research is concerned with the production of new knowledge, which may or may not is used in practice. Innovation, on the other hand, is concerned with the processes of change in the production and marketing of goods and services - changes that may or may not be driven by research [1].

In agricultural development, innovation has been defined as "the process by which individuals or organizations master and implement the design and production of goods and services that are new to them, irrespective of whether they are new to their competitors, their country, or the world" [2].

In the context of farming, innovations are concerned primarily with increasing production - of food, fodder, secondary products - and enhancing quality - of produce, growing conditions, production process. They typically involve one or more of the following five areas [3]:

- Crops - biological and genetic changes, such as the introduction of new breeds or varieties which have specific advantages, i.e., being higheryielding or more resistant to certain weather/soil conditions; the introduction of new species that extend the farming calendar or the type of farming; new techniques (e.g., grafting); turning plant produce into cash crops, e.g., olive oil (olives), wine (grapes), beer (cereal grain); etc.
- Animals - similar biological and genetic changes as listed above; new ways of husbanding the existing animals in ways to make them more productive - e.g., the exploitation of animals for their secondary products (wool, milk, blood, traction) rather than just for their meat and hides; etc. Growing conditions - the addition of manure or other fertilizer; raising soil depth; drainage or irrigation; increased soil working (digging, plowing); terraces to avoid soil erosion or to acquire additional cultivation space; windbreaks; supplying fodder or improved grazing to animals; etc.

Innovation is stimulated by the interaction of individuals and organizations with diverse often conflicting - stakes in the management of scarce resources or the governance of productive processes. For this reason, interventions to promote innovation often involve what may be called "innovation brokering" or "facilitation," which focuses on enabling other actors to engage in critical reflection, experimentation, and joint learning [4].

The institutional arrangements and standard operating procedures of agricultural $R \& D$ organizations have tended to lag behind the evolution of thinking on innovation processes and systems [5]. Consequently, most agricultural research organizations continue to top focus on expanding the supply of new technologies rather than on linking research more effectively to change processes on farms and in value chains.

\section{METHODOLOGY}

This work is based on a review of the latest research papers authored by specialists in agricultural research. For our analysis, we 
used official data and publications of the State Committee of the Republic of Uzbekistan and the Ministry of Agriculture and Water Resources.

Results. The main categories of agricultural producers in Uzbekistan

Agriculture is one of the leading sectors of Uzbekistan's economy. The contribution of the agricultural sector to Uzbekistan's GDP was $28.8 \%$ in 2018 (Figure 1). Crop production in 2018 accounted for $53.2 \%$ and livestock breeding for $46.8 \%$ of the cost of agricultural products. 3.7 million people worked in the agricultural sector in 2017 (27.2\% of the total number of employed). Almost half of the country's population lives in rural areas [6].

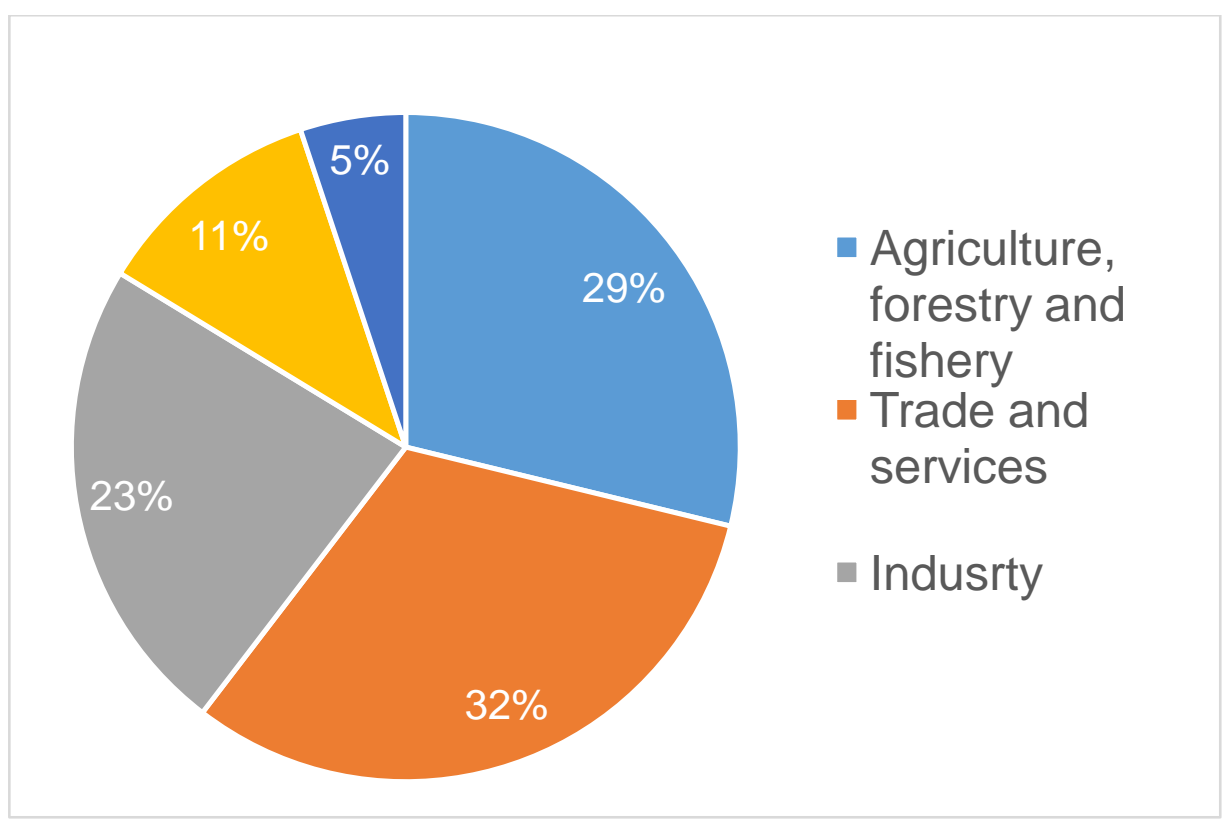

Figure 1. Sectoral structure of Uzbekistan's GDP in 2018, in \%.

At the same time, agriculture is one of the sectors of the economy, which is the most regulated by the state. The property rights of major large agricultural producers, farmers, are extremely weakly protected; methods for regulating their activities are, in fact, taken from the Soviet past. The markets for many types of agricultural products and production resources and services for the sector are not developed. The agrarian sector is in desperate need of reform. Although Uzbekistan has already headed for system economic reforms for two years, there is almost no change in agriculture.
From the late 1980s, Uzbekistan, like other republics of the former Soviet Union, began the transition to a market economy, including in the agrarian sector. Significant areas of agricultural land were transferred from former collective and state farms for the development of private farms of the rural population in 1989. By 1994, all collective and state farms were transformed into cooperative farms - shirkats. In the early 2000s, private farms replaced the shirkats as the main subjects of farm-market agriculture. At the same time, most of the agricultural 
products are not produced by them, but by small dehqan (personal subsidiary) farms.

Table 1. Distribution of agricultural land by land users, in thousands of hectares in 2017

\begin{tabular}{|c|c|c|c|}
\hline & Arable land & $\begin{array}{r}\text { Orchards } \\
\text { and vineyards }\end{array}$ & $\begin{array}{c}\text { Hayfields } \\
\text { and pastures }\end{array}$ \\
\hline Farms & 3472.9 & 295.0 & 1481.3 \\
\hline $\begin{array}{c}\text { Dehqan } \\
\text { farms }\end{array}$ & 420.2 & 80.3 & - \\
\hline Other farms & 142.2 & 10.3 & 19643.1 \\
\hline Total & 4035.3 & 385.6 & 21124.4 \\
\hline
\end{tabular}

Source: State Statistics Committee of the Republic of Uzbekistan.

The farms, possessing $85.2 \%$ of the land allocated for cultivation area, orchards, and vineyards (data of 2017), produced only $27.3 \%$ of agricultural products in 2018. $70.0 \%$ of the total agricultural output in 2018 was accounted for dehqan farms owning only $11.3 \%$ of the land allocated for cultivation area, orchards, and vineyards. The situation is associable with the Soviet past, when the majority of main types of agricultural products were produced not on large farms (collective and state farms) but on personal household plots of land.

Crop production in Uzbekistan is significantly on irrigated and only to some extent on rainfed agriculture. Wheat and cotton are the most important agricultural crops in the irrigated areas. Cotton and wheat are grown either continuously or in crop rotation. In Uzbekistan, the area under irrigated winter wheat has increased to ensure national food security, so that the former, long-cycle cropping system cotton-alfalfa was replaced mainly by shorter crop rotation of spring-sown cotton and winter wheat. As a result, the cereal production in Uzbekistan during the last decade has increased almost 20 times, with the main increase attributed to wheat production. In Uzbekistan, wheat production has increased by more than 600 percent, reaching around 8.1 metric tons (MT). On the other hand, cotton production went down to about $21 \%$ due to decreased planting areas (Table 2). Fruit and

vegetables are also becoming important in some regions as private markets expand. The absence of alfalfa in present crop rotations has diminished humus and considerable micronutrients' levels in the soil. It has also reduced the soil structure benefits derived from alfalfa's root system. Crop rotation with fodder legumes or pulses is extremely important for soil health and management of plant diseases. 
Table 2. Trends on area and productivity for selected crops in Uzbekistan, 1991-2016

\begin{tabular}{|c|r|r|r|r|r|r|r|r|r|r|}
\hline \multirow{2}{*}{ Year } & \multicolumn{2}{|c|}{ Wheat } & \multicolumn{2}{c|}{ Cotton } & \multicolumn{2}{c|}{ Fruits } & \multicolumn{2}{c|}{ Intensive orchards } & \multicolumn{2}{c|}{ Vegetables } \\
\cline { 2 - 11 } & $\begin{array}{c}\text { Area, } \\
\text { '000 ha }\end{array}$ & $\begin{array}{c}\text { Yield } \\
\text { t/ha }\end{array}$ & $\begin{array}{c}\text { Area, } \\
\text { '000 ha }\end{array}$ & $\begin{array}{c}\text { Yield, } \\
\text { t/ha }\end{array}$ & $\begin{array}{c}\text { Area, } \\
\text { '000 ha }\end{array}$ & $\begin{array}{c}\text { Yield, } \\
\text { t/ha }\end{array}$ & $\begin{array}{c}\text { Area, } \\
\text { '000 ha }\end{array}$ & $\begin{array}{c}\text { Yield, } \\
\text { t/ha }\end{array}$ & $\begin{array}{c}\text { Area, } \\
\text { '000 ha }\end{array}$ & $\begin{array}{c}\text { Yield, } \\
\text { t/ha }\end{array}$ \\
\hline 1991 & 226.0 & 1.71 & 1720.5 & 2.72 & 50.0 & 15.8 & 0 & 0 & 165.6 & 18.8 \\
\hline 2000 & 1027.8 & 2.76 & 1444.5 & 2.18 & 139.0 & 5.1 & 0 & 0 & 34.8 & 18.3 \\
\hline 2010 & 1155.6 & 4.89 & 1450.3 & 2.54 & 180.2 & 9.5 & 10.1 & 15.32 & 172.9 & 25.6 \\
\hline 2015 & 1145 & 5.81 & 1444.5 & 2.18 & 261.9 & 12.4 & 36.9 & 21.41 & 194.0 & 30.2 \\
\hline 2016 & 1135 & 5.92 & 1423.1 & 2.61 & 266.9 & 11.8 & 40.5 & 24.24 & 205.4 & 27.1 \\
\hline
\end{tabular}

Source: Ministry of Agriculture and Water Resources, Uzbekistan, 2016

Conclusion. Today, Uzbekistan has all the necessary socio-economic bases for deepening the innovation process and strengthening the innovation base.

However, there are problems with the way of innovative development of the agrarian sector, or in other words, the implementation of innovative projects in one or even several farms, because: firstly, farms and agroprocessing entities are currently ordering research and research. Insufficient participation in financing; Secondly, the economic entity cannot independently carry out research and development of advanced innovation technologies; thirdly, lack of knowledge of agricultural producers and processors for the use of new technologies and new varieties, they need to use the services of scientists and specialists, and farmers face some difficulties in the processing and sale of products; Fourthly, the insufficiency of the developers' demand for innovation development by scientists of higher education and research institutions is not well established; Fifth, irresponsibility of some agricultural producers [7].

Agriculture is a vital sphere in Uzbekistan. The well-being of the large rural population, as well as ensuring the country's food security, depends on its sustainable development.

In this regard, the main directions of innovative development of agricultural sectors in Uzbekistan can be classified as follows:

- $\quad$ Developing new high-yielding crop varieties resistant to diseases through the use of cellular engineering, molecular genetics, and traditional breeding; 
- $\quad$ Adaptation of highly productive crop varieties of foreign selection to soil and climate conditions in Uzbekistan;

- Development and introduction of new systems of land use and water-saving technologies;

- Development and introduction of resource-saving systems of machines for complex mechanization of technological processes in agriculture;

- Development and use of highly effective bio preparation for control of diseases and plant pests;

- Creation of highly productive breeds of farm animals;

- $\quad$ Adaptation of agricultural animals of foreign selection to the conditions of Uzbekistan;

- Development and introduction of nonwaste technologies of processing of products of animal origin;

- Creation of new resource-saving systems of machines for complex mechanization of technological processes in animal breeding;

- Development of technical means of water supply on the basis of renewable natural energy sources;

- Improvement of systems for keeping and feeding animals;

- Development of new methods of diagnostics, prevention, and treatment of animals.

For successful innovative development of agriculture, it is necessary to combine state support measures aimed at stimulating innovation proposals with measures promoting innovative technological development of the industry.
1. Andre Devaux, Maximo Torero, Jason Donovan, and Douglas Horton. Agricultural innovation and inclusive value-chain development: a review. Journal of Agribusiness in Developing and Emerging Economies Vol. 8 No. 1, 2018 pp. 99-123 Emerald Publishing Limited

2. World Bank, Agricultural Innovation Systems: An Investment Sourcebook, World Bank 2012, Washington, DC.

3. Evenson, R. International diffusion of agrarian technology. The Journal of Economic History 1974, 34(1): 51-93.

4. Klerkx, L., Hall, A. and Leeuwis, C., "Strengthening agricultural innovation capacity: are innovation brokers the answer?", International Journal of Agricultural Resources, Governance and Ecology, Vol. 8 Nos 2009. 5/6, pp. 409438.

5. Hall, A., "Challenges to strengthening agricultural innovation systems: where do we go from here?", in Scoones, I., and Thompson, J. (Eds), Farmer First Revisited: Innovation for Agricultural Research and Development, Practical Action Publishing, Rugby, 2009. pp. 3038.

6. The data of the State Statistics Committee of the Republic of Uzbekistan - https://www.stat.uz/

7. Djuraevna, Rustamova \& Xalmirzaevich, Makhmudov \& Mexmonovich, Yuldashev. Innovative Activities of Agriculture In Uzbekistan. World Science, 2019. 3. 13-16.

\section{REFERENCES}

